Scientific note

\title{
A scientific note on the use of stingless bees for commercial pollination in enclosures
}

\author{
Ester Judith SlaA*, Luis Alejandro SANCHEZ, Miriam SANDI, William SALAZAR \\ PRAM, Utrecht University, The Netherlands \& CINAT, Universidad Nacional, \\ Costa Rica, Apartado Postal 475-3000, Heredia, Costa Rica
}

(Received 3 January 1999; revised 23 September 1999; accepted 6 November 1999)

pollination / enclosure / stingless bees / Salvia

Stingless bees are considered to be very important pollinators in the tropics, and they are known to effectively pollinate at least 9 crops [1]. Nevertheless, they are seldomly used for commercial pollination. To our knowledge, only one study has been published using stingless bees for crop pollination [2]. In that study, Nannotrigona testaceicornis was used successfully to pollinate strawberries in a greenhouse in Japan. There are several advantages that might make stingless bees more suitable for the pollination of certain crops than the commonly used honeybee $[1,3]$. The fact that they lack a functional sting makes them especially suitable for pollination in enclosures. In our study, we compared the pollinating activity between two species of sting-less bees and honeybees on the ornamental plant Salvia farinacea var. strata (Lamiaceae) in enclosures. S. farinacea is an ornamental herbaceous plant, with small $(\mathrm{ca} .1 \mathrm{~cm})$ purple and white flowers. It is commercially grown for seed export, usually in enclosures to ensure the production of pure seeds.
Experiments were carried out at the seed company Flora Feliz, Cartago, Costa Rica (9 43' 51' ' N, 83 54' 51', W, altitude 1388 $\mathrm{m})$. Flower visitors of $S$. farinacea were captured in an open-air patch of 40 plants in December 1995. Pollination experiments were conducted in four netted enclosures $(6 \times 3 \times 3 \mathrm{~m})$ in April 1996. Each enclosure contained 60 plants that were pollinated by one of the three bee species during one month, or were left without pollinators (control). The following bee species were used: Nannotrigona testaceicornis, Tetragonisca angustula, and Apis mellifera. N. testaceicornis is a small robust bee with a body length of 4.1-4.2 mm. Colonies contain a few thousand individuals and the species is quite common in the Neotropics. T. angustula is a small, slender bee with a body length of 4.4-4.7 mm. It is the most abundant stingless bee species in Costa Rica with a colony size up to 5,000 individuals. We used a 5-frame hive of Africanized A. mellifera with approximately 10,000 workers.

Bees in the family Apidae were the most common visitors of $S$. farinacea in the open

\footnotetext{
* Correspondence and reprints

E-mail: jslaa@una.ac.cr
} 
Table I. Foraging and seed production in 4 enclosures containing Salvia farinacea provided or not with different species of bee pollinators (mean $\pm \mathrm{SE}$ ). Data in the last column were calculated as (seed yield with pollinators - seed yield control)/(foraging activity).

\begin{tabular}{lccc}
\hline Bee species & $\begin{array}{c}\text { Foraging activity } \\
\text { \# visits·plant }\end{array}$ & $\begin{array}{c}\text { Seed yield } \text {.in }^{-1} \\
\mathrm{~g} \cdot \text { seed } \cdot \text { plant }\end{array}$ & $\begin{array}{c}\text { Seed yield / foraging activity } \\
\mathrm{g} \cdot \text { seed / \# visits } \cdot \mathrm{min}^{-1}\end{array}$ \\
\hline A. mellifera & $4.6 \pm 4.1$ & $1.02 \pm 0.15$ & 0.21 \\
N. testaceicornis & $3.3 \pm 3.4$ & $0.77 \pm 0.12$ & 0.22 \\
T. angustula & $2.4 \pm 2.8$ & $0.61 \pm 0.08$ & 0.24 \\
Control & 0 & $0.04 \pm 0.02$ & \\
\hline
\end{tabular}

(73\% of all visitors; $n=286$ ). Both $A$. mellifera and T. angustula, used in our experiments, visited $S$. farinacea in good numbers (20 and $23 \%$ of all bees, respectively). The other bee visitors were 2 other stingless bee species, Partamona aff. cupira (42\%) and T. fulviventris (15\%).

In the enclosure experiment, bees visited the flowers mostly during the morning. On a daily basis, the plant visitation rate of A. mellifera was almost twice as high as that of T. angustula. N. testaceicornis showed an intermediate foraging activity (Tab. I).

Seed production was very low in the control enclosure without pollinators in comparison with that in the enclosures provided with bees (Tab. I). Comparison of the three bee species showed that pollination was most effective for A. mellifera, followed by N. testaceicornis and T. angustula (Tab. I). Pollination by all tested pollinators resulted in the production of good quality seeds with seed weight (953-1,176 seeds/g) and germination rate $(61-71 \%)$ similar among the enclosures.

The lower seed production obtained with sting-less bees in comparison with honeybees may have been a consequence of their lower foraging activity, which in turn was probably related to their much smaller population of foragers. Seed yield evaluated per unit of foraging activity, was similar for all three species of bees (Tab. I).

This study shows that stingless bees can be effective pollinators in enclosures and can therefore be a valuable alternative to honeybees for commercial crop pollination.

\section{ACKNOWLEDGEMENTS}

We thank Rene Gross and Flora Feliz for the arrangements of the enclosures and the plant material. Fernando Ramírez is thanked for the management of the honeybee colony. Koos Biesmeijer made valuable comments on the manuscript. This study was financially supported by NUFFIC, via the 'Programa Regional de Apicultura y Meliponicultura'.

Note scientifique sur l'utilisation d'abeilles sans aiguillon pour la pollinisation commerciale sous abris.

Eine wissenschftliche Notiz über die Nutzung von stachellosen Bienen zur kommerziellen Bestäubung in Gewächshäusern.

\section{REFERENCES}

[1] Heard T.A., The role of stingless bees in crop pollination, Annu. Rev. Entomol. 44 (1999) 183-206.

[2] Maeta Y., Tezuka T., Nadano H., Suzuki K., Utilization of the Brazilian stingless bee, Nannotrigona testaceicornis as a pollinator of strawberries, Honeybee Sci. 13 (1992) 71-78 (in Japanese).

[3] Roubik D.W., Stingless bee colonies for pollination, in: Roubik D.W. (Ed.), Pollination of cultivated plants in the tropics, FAO Agricultural Services bulletin 118, Rome, 1995. pp. $150-154$. 